\title{
SALLYANN GOODALL
}

\section{INTRODUCTION}

Professor Julius Hackethal is a wellknown general surgeon in West Germany. In 1975 he made plans to emigrate to South Africa because he was convinced he could carry out his ideas of an ideal patient-friendly clinic here

In 1976 his first popular medical book, dealing with a dozen cases of medical error rocked medical circles in Germany, delighting their critics, and persuading him to stay at home. He has since published guides to educate people how to take more responsible decisions for their own health matters. He visited Prof. Chris Barnard in Cape Town in 1980.

In the 1960s he was in charge of nurses' training in Erlangen near Nuernberg, and it was here that he developed the code of conduct given below. This code is handed out as a circular to all nursing staff joining his work. It must be remembered that in Germany it is the doctor who is boss on the general hospital ward. It is he who is responsible for the nurses on his team in the private clinic, not a matron.

Prof. Hackethal has been the father of a more responsible public attitude towards health in Germany and has drastically revised attitudes towards patients in an alienating and technologically orientated world.

\section{TO ALL MY NURSES . . .}

To all my nurses and sisters - male ones included. (Perhaps this can be useful outside my practice too.) . . .

To be a nurse to sick people, to give sisterly love and attention and be helpful to suffering people - I can't think of a more wonderful career. On the other hand, to be a patient calling for help in pain and fear, and to be dismissed heartlessly by a mechanic in a nurses cap what could be more unbearable!

The author of this article has been patient and secretary to Prof J Hackethal.

\section{OPSOMMING}

Prof Julius Hackethal is 'n bekende sjirurg in Wes-Duitsland wat 'n groot omwenteling in houdings teenoor pasientsorg aldaar teweeggebring het.

Hy het 'n gedragskode vir verpleegkundiges opgestel wat gegee word aan elke lid van die verpleegpersoneel wat by sy kliniek aansluit. 'n Vertaling van die kode verskyn hier - die wyse beginsels kan oral toegepas word.

It is interesting that amongst many qualified people, some who have excellent knowledge and are perfect technically, those who care for patients like a mother cares for the sick child are extremely rare indeed. Sometimes I even feel, the higher the qualification, the less love is invested in one's work. Of course there are exceptions.

I would like all my nurses to be sisterly. I would rather have someone who is unqualified who deserves the name sister than an unfriendly, insolent, or even ice-cold person with the highest qualification. If necessary I can do injections, dressings, and remove stitches myself. Feeding, rubbing, fixing beds, and shaking pillows I'm not so good at - and many other things that are part of a woman's love and are good for sick people.

I really expect my sisters and nurses to look after patients in a way that they should be able to take for granted. I know that many of you have the right attitude, but generally things should be far, far better.

\section{A FEW SPECIFIC POINTS}

- There is never an excuse for being rude to a patient. No ill person can behave so badly that rudeness or unkindness is justified. Your being rude to a patient only once is reason enough for me to release you from duty immediately. Naturally, everyone has the right to complain about a patient. Sometimes it is even your duty to do so. This should be done to your superior.

- We are under contract to our patients. They are not our hirelings or servants. This doesn't mean that we must grovel to them, but it does mean fair fulfilment of our accepted contract. The contract reads: Make me healthy as soon as possible, without tormenting or irritating me at the same time.

- Patients are not only physically, but almost always also psychologically ill. Some less, some more. Usually more than we suspect. They should not be judged by the same standards we use for healthy people. They need more patience, more consideration, more kindness, more concern.

- When a patient complains about something, listen to him quietly and without taking sides. Give this complaint on to your superior. If the patient does not want this, you should keep quiet about it. But do make him aware of the fact it is difficult to remove his cause for complaint if the superior does not know.

- Every person employed here should always practise to read patients' desires from their eyes. The good nurse helps before she is asked.

- There are many patients who are frightened of sisters and nurses because of other hospital experiences. They fear that they might be purposefully hurt or be given the wrong medicine. This is a terrible thought to have, but there are such thoughts. Everyone should know this.

- There is never a reason for a nurse to take a break outside of the official breaks. There are always patients waiting for a kind word, hoping that you will come and straighten their sheets. 
- On gossip - ward-gossip means denigrating patients, colleagues or doctors when they cannot defend themselves. Unfortunate things become mean jokes. When people give you something to complain about, say it to their faces, or keep quiet about it. Everything else is unfair. I want open relationships, am against anything behind someone's back. Diplomatic niceties are unnecessary. You may and should tell me if you feel unfairly treated. You will receive either a reason for my actions or an apology.

- I am against forced authority and hate dictators. If I cannot prove that I deserve the position of director of our clinic, I should resign. Please make me aware of this if I should fail to notice it myself. To be the director of a clinic means working more than the others, not letting the others work to strengthen one's laziness. Please remind me about this if I should forget it one day. I

\section{Vervolg vanaf P37 \\ Objektiwiteit}

'n Leier moet probeer om situasies en gebeure te evalueer sonder om kant te kies of subjektief te raak. Om empatie te betoon, maar nog objektief te bly, is ' $n$ vaardigheid wat geoefen moet word $(5: 156)$. 'n Balans tussen empatie en objektiwiteit is noodsaaklik vir effektiewe leierskap.

\section{Persoonlikhede}

Alhoewel die persoonlikheidsteorie in leierskap reeds verwerp is, is daar navorsers (1:5) wat van mening is dat sekere eienskappe merkbaar is by effektiewe leiers, onder andere:

- selfvertroue met 'n gevoel van persoonlike identiteit

- 'n sterk dryfkrag vir verantwoordelikheid

- energie

- aanvaar implikasies van besluite en optredes

- aanvaar interpersoonlike spanning

- goeie frustrasie-toleransie

- kan gedrag beïnvloed

- avontuurlustig en oorspronklik

— inisieer inisiatief $(1: 15)$. may and will not expect anything from my colleagues which I am not prepared to do myself.

- We need order here. Not an exaggerated one, but something sufficient. Without punctuality there is no order. Someone has to be in charge of the ward. This is the ward sister or her representative. Their requests are to be carried out immediately and are not to be contradicted. Complaints about them should be addressed to me.

- Avoiding work at someone else's cost is unfair. Everyone must do his share so that work runs smoothly. There is no place for laziness here.

- Absolute cleanliness is extremely important. Nurses with uncaredfor hands or even dirty fingernails are unbearable. You must wash your hands again and again, and bath or shower before you come on duty. Daily. A bit of perfume is like a disinfectant, but

\section{SAMEVATTING}

Leierskap is in die verlede altyd geassosieer met aggressie, manlike karaktertrekke en dominering, terwyl passiwiteit met vroue vereenselwig is. Dit is duidelik dat dit nie die geval is nie en dat daar nie 'n spesifieke leierskapsteorie is wat die beste is en aanbeveel kan word nie.

Leiers is nooit net mens geörienteerd of net taak geörienteerd nie, maar het gewoonlik komponente van albei in ' $n$ mindere of meerdere mate.

Daar is ook baie faktore wat leierskap kan beïnvloed, naamlik persoonlikheid, situasies, doelstellinge, verhoudinge, omgewings en volwassenheid van die volgers.

Leiers moet van hulle eie persoonlikhede en die invloed wat dit op andere mag hê bewus wees.

Dit word egter aanbeveel dat 'n leier sy styl sal aanpas by die situasie en optree volgens wat die probleem vereis, met ander woorde, die situasie leierskap teorie navolg. it is not a substitute for soap and water.

- Sick people need a lot of rest. Sleep should be encouraged, and disturbed as little as possible. Avoid loud noises and harsh light whenever you can.

- There is an absolute ban on alcohol during your duty, your breaks, and for eight hours before the start of your duty.

- Patients do not mind if they occasionally have to wait because a more serious case needs attention. A few words asking for their consideration works miracles. If you pay attention to little things you can contribute a great deal towards the patients' recovery and satisfaction.

- All sisters and nurses should work towards becoming good friends. My goal is to offer a community of friends to our patients. Whoever destroys this through his or her behaviour is unsuited to this work.

\section{Slot}

Verpleegleierskap is een van die hedendaagse probleme in die verpleegadministrasie en dit is noodsaaklik dat meer aandag in studente se opleidingsprogramme aan hierdie belangrike aspek gegee word. Verpleegkundiges in elke area van gesondheidsorg dienslewering moet opgelei word om 'n leier te wees, hetsy om pasiënte of personeel te lei.

Die wanbegrip by personeel dat net persone in bestuursposisies leiers is, moet uit die weg geruim word. Dit het tyd geword dat mense begin besef dat daar ' $n$ verskil tussen bestuurders en leiers is.

\section{BRONNELYS}

1. Douglas, L.M. (1980) The effective nurse: leader and manager. St Louis. C.V. Mosby.

2. Douglas, L, Bevis, O. (1979) Nursing management and leadership in action. London. C.V. Mosby. 3rd Ed.

3. Deep $S$. (1979) Human relationships in management. London. Glencoe Publishing.

4. Heimann, C.G. (1976) Four theories of leadership. Joumal of Nursing Administration June 1976.

5. Longest, B.B. (1980) Management pracrices for the health professionals. Virginia. Prentice Hall.

6. Mariner, A. (1980) Guide to nursing management. London. C.V. Mosby.

7. McConnel. E. (1980) How to choose a leadership style. Nursing Joumal, March

8. Moloney. M.M. (1980) Leadership in nursing: theories, strategies, action. London. C.V. Mosby.

9. Searle. C. (1976) Verpleegadministrasie 001 Gids 1, Pretoria, Unisa.

10. Tyndall. A. (1979) Situation leadership theory. Jouma of Nursing Administration Vol. 2. no. 2. June 1979. 